\title{
ANALISIS FAKTOR PADA KINERJA KEUANGAN DAN MEDIASI STRUKTUR MODAL PADA KOMITE AUDIT DI PERUSAHAAN PROPERTY
}

\author{
Tri Indah Sri Mulyaningsih \\ Universitas Negeri Surabaya \\ trisrimulyaningsih16080574118@mhs.unesa.ac.id
}

\begin{abstract}
Financial performance evaluates how successful the company has achieved business activities. The purpose of this research is to analyze if financial performance (ROA) affected by firm size, investment opportunity set (IOS), dividend (DPR), audit committee, and capital structure (DAR). Also the mediation effect of capital structure in the audit committee to financial performance. Population in this research is 56 property sector companies on BEI (www.idx.co.id). The sample in this research is 28 property companies (period 2014-2018) chosen by purposive sampling. This study uses a type of conclusive causal. The data analysis technique used path analysis with IBM SPSS 20. The results show that IOS has a significant effect on financial performance. Firm size, dividend \& capital structure has a significant negative effect on financial performance. The audit committee does not significant to financial performance and capital structure (DAR). And also capital structure (DAR) does not mediate the audit committee to financial performance.
\end{abstract}

Keywords: audit committee; DAR; DPR; financial performance; IOS.

\section{PENDAHULUAN}

Perkembangan ekonomi di Indonesia mengalami pertumbuhan yang baik. Hal tersebut didukung dengan data perekonomian Indonesia tahun 2018 yang naik dari tahun 2017 sebesar 5,07\% menjadi $5,17 \%$, serta gross domestic bruto atau PDB memiliki basic price hingga Rp14 Triliun (Kemenkeu, 2019). Dengan adanya perkembangan ekonomi yang baik tersebut, mampu menumbuhkan minat investor dalam berinvestasi di Indonesia. Perkembangan yang baik pada perekonomian ini, juga akan berdampak baik bagi perusahaan-perusahaan di Indonesia. Tujuan utama didirikannya perusahaan untuk meningkatkan kesejahteraan investornya (Fachrudin, 2011), di mana kesejahteraan para investor dapat diketahui melalui peningkatkan kinerja keuangan perusahaan (Detthamrong, et al. 2017). Kinerja keuangan memiliki daya tarik untuk diteliti karena memiliki informasi dan mempredikasi seberapa besar kapasitas yang dimiliki perusahan dalam menghasilkan cashflow dari kegiatan-kegiatan nya (Nuzil, 2017). Kinerja keuangan terdiri dari aset, pendapatan serta keuntungan, yang dapat mencerminkan kondisi perusahaan (Marinda, et al. 2014). Sehingga, kinerja keuangan dapat berpengaruh terhadap merger-akuisi perusahaan dan kredit yang diajukan atau diberikan.

Para investor dapat mempertimbangkan keputusan penanaman modal pada perusahaan saat mengetahui performa atau kinerja pada keuangan suatu perusahaan. Kinerja keuangan dapat memberikan gambaran bagaimana keberhasilan yang telah dicapai kegiatan bisnis suatu perusahaan (Marinda, et al. 2014). Pencapaian kegiatan bisnis perusahaan dapat digambarkan melalui laba yang dihasilkan. Seperti yang disampaikan oleh Pervan \& Visic (2012) yaitu tingkat laba merupakan indikator dalam kinerja keuangan perusahaan. Laba atau profit yang diterima perusaahaan mampu menandakan bagaimana kondisi keuangan perusahaan tersebut. Salah satu alat ukur laba adalah return on assets atau ROA, yang bisa menilai bagaimana suatu perusahaan menggunakan aset atau sumber daya untuk menghasilkan lebih banyak pendapatan. ROA suatu perusahaan yang semakin tinggi menandakan semakin baik nya profit yang diterima oleh perusahaan tersebut.

Sejalan dengan kebutuhan perusahaan untuk meningkatkan laba yang diterimanya yang berarti penjualan perusahaan harus mengalami peningkatan, menurut Asmara (cnbc.com 2018) pemerintah memperkirakan konsumsi masyarakat pada tahun 2018 tumbuh lebih baik sebesar 5 persen, pada segi investasi, juga dapat tumbuh stabil diangka 5 persen. Namun, pada data perolehan laba yang diproksikan dengan ROA pada 9 sektor perusahaan di Indonesia pada tahun 2014-2018 terdapat 
peningkatan dan penuruan yang fluktuatif. Adapun data grafik ROA ke 9 sektor perusahaan di Indonesia disajikan pada gambar 1.

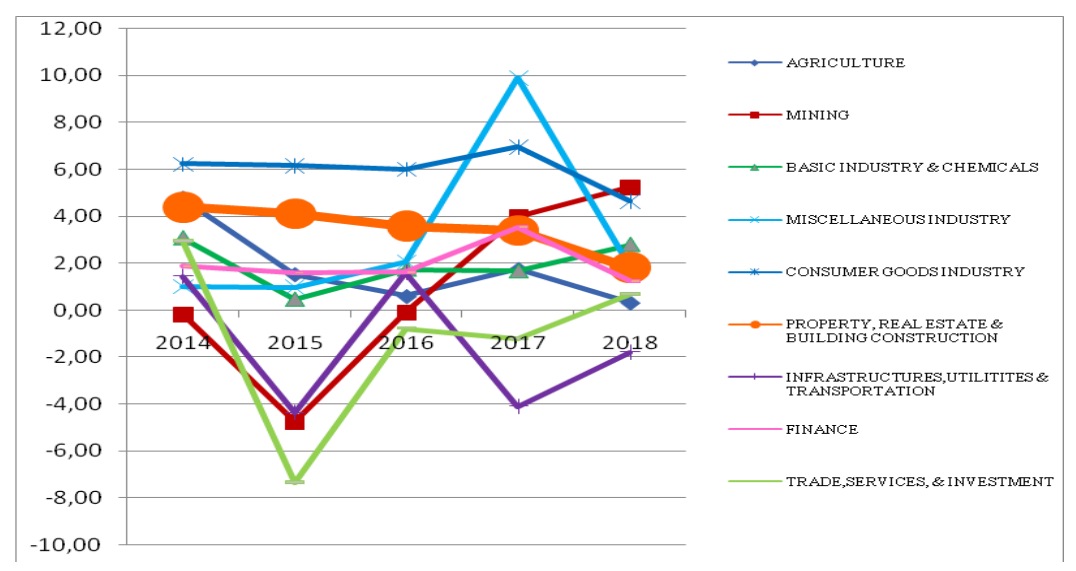

Sumber : idx.co.id (2019, data diolah)

\section{Gambar 1. ROA SEKTOR-SEKTOR PERUSAHAAN DI INDONESIA}

Berdasarkan gambar 1, terdapat 9 sektor perusahaan yang ada di Indonesia. Sektor-sektor tersebut penulis tandai dengan menggunakan warna-warna yang berbeda. Untuk sektor agriculture ditandai dengan warna biru muda, sektor mining ditandai dengan warna merah, sektor basic industry \& chemicals ditandai dengan warna hijau tua, sektor miscellaneous industry ditandai dengan warna ungu, sektor consumer goods menggunakan warna biru, sektor property menggunakan warna orange, sektor infrastruture, utilities \& construction menggunakan warna biru muda, sektor finance menggunakan warna pink, lalu untuk sektor trade, services \& investment menggunakan warna hijau muda. Profitabilitas 8 perusahaan di Indonesia mengalami kenaikan dan penurunan ROA yang fluktuatif. Sedangkan pada sektor property (ditandai warna orange) mengalami penurunan yang konsisten mulai tahun 2014-2018. Lalu, menurut Gideon (Liputan6.com 2018) Property Price Index kuartal II 2018 atau indeks harga property berada pada angka 105,9. Indeks ini merupakan indeks tertinggi sejak 2015. Kemudian pada kuartal III 2018naik sebesar 2,3\% menjadi 108,3. Property Supply Index atau indeks persediaan/ pendapatan property pada kuartal III 2018 mengalami pertumbuhan 13\% menjadi 165,3. Peningkatan ini terjadi karena respon penjual terhadap meningkatnya harga property. Terlihat perbedaan data pada pergerakan ROA sektor property yang mengalami penurunan yang konsisten daripada sektor-sektor lain yang tercatat pada IDX dengan data pada berita yang disampaikan oleh Gideon (Liputan6.com 2018), sektor property mengalami peningkatan pendapatan (propert supply index) yang konsisten, sehingga sektor property dapat dijadikan objek penelitian karena fenomena yang terjadi tersebut.

Pada penelitian kali ini, akan menggunakan ROA (return on assets) sebagai proksi rasio profitabilitas dalam penilaian kinerja keuangan. ROA menampilkan kemampuan manajemen perusahaan dalam pengelolaan aset untuk pendapatan perusahaan secara efektif,sehingga mampu menampilkan proporsi profitabiltas yang baik (Pradhan \& Paudel, 2017). Menurut Sudana (2015:22), ROA yang semakin besar, memiliki makna jumlah laba yang dihasilkan dapat sama dengan aset atau lebih besar. Ada beberapa variabel yang memengaruhi kinerja keuangan, yang pertama adalah ukuran perusahaan. Menurut Putra \& Badjra (2015) ukuran perusahaan memberikan makna besar atau kecil nya kelayakan suatu perusahaan dalam memperoleh tambahan modal eskternal dan profitabilitas. Untuk ukuran perusahaan yang besar akan mempermudahkannya memperoleh modal eksternal dan meningkatkan profitabilitas melalui peningkatkan produktivitas perusahaan. Penelitian Pervan \& Visic (2012) dan Dogan (2013) memberikan hasil penelitian positif signifikan pada ukuran perusahaan ke kinerja keuangan. Penelitian Olawale, et al. (2017) menyatakan hasil signifikan negatif Sedangkan menurut Putra \& Badjra (2015) dan Fachrudin (2011) menyatakan hasil non signifikan. 
Tri Indah Sri Mulyaningsih. Analisis Faktor pada Kinerja Keuangan dan Mediasi Struktur Modal pada Komite Audit di Perusahaan Property

Faktor kedua yang memengaruhi kinerja keuangan adalah IOS (investment opportunity set). Jumlah peluang investasi bagi perusahaan harus membuat keputusan yang menghasilkan pengembalian keputusan investasi yang optimal (Yuliani, et al. 2018). Ada beberapa faktor yang dapat dipertimbangkan dalam memaksimalkan kinerja keuangan suatu perusahaan, salah satu nya adalah faktor keputusan investasi (Marinda, et al., 2014). Menurut Sanjabi \& Jamshidinavid (2017), terdapat pengaruh signifikan positif terkait IOS terhadap kinerja keuangan. Penelitian Hutchinson \& Gul (2004) menyatakan terdapat pengaruh signifikan negatif. Sedangkan menurut Marinda, et al., (2014) dan Yuliani, et al., (2018) menyatakan tidak terdapat pengaruh.

Faktor ketiga yang memengaruhi kinerja keuangan adalah dividen. Kebijakan dividen perusahaan memberikan informasi bagaimana laba akan disesuaikan ketika diumumkan. Keuntungannya yang didapat perusahaan dapat digunakan sebagai pembayaran dividen atau sebagai laba ditahan yang digunakan untuk pengembangan investasi (Tornyeva \& Wereko, 2012). Perusahaan yang melakukan pembagian dividen, akan berdampak pada laba ditahan. Akan tetapi, dengan membagikan dividen, dapat mengurangi agency cost (Nuzil, 2017). Sehingga, pembagian dividen berdampak pada kinerja keuangan perusahaan jika manajemen tidak memperhitungkan dalam penggunaannya. Penelitian menurut Kanwal \& Hameed (2017), M'rabet \& Boujjat (2016), dan Tornyeva \& Wereko (2012) terdapat pengaruh signifikan positif terkait dividen terhadap kinerja keuangan. Penelitian K \& Akash (2018) menyatakan hasil signifikan negatif. Sedangkan menurut Nuzil (2017) menyatakan hasil non signifikan.

Faktor keempat yang memengaruhi kinerja keuangan yaitu komite audit. Menurut Detthamrong, et al., (2017) komite audit merupakan sub-komite direktur yang berwenang secara independen pada penyusunan kinerja keuangan serta pengungkapan yang akurat sesuai standar pelaporan. Komite audit juga memiliki tujuan dalam peningkatan kredibilitas dan integritas informasi keuangan perusahaan dan untuk meningkatkan kepercayaan publik terhadap kinerja keuangan yang dimiliki suatu perusahaan (Tornyeva \& Wereko, 2012). Penelitian Tornyeva \& Wereko (2012) memiliki hasil signifikan antara komite audit terhadap kinerja keuangan. Namun, menurut Detthamrong, et al., (2017) dan Hutchinson (2005) terdapat pengaruh signifikan negatif. Penelitian Olayinka (2019) menyatakan hasil non signifikan.

Faktor kelima yang memengaruhi kinerja keuangan adalah struktur modal. Perusahaan dapat melakukan keputusan pendanaan dengan mempertimbangkan pilihan-pilihan antara utang dan modal sendiri. Pendanaan tersebut dapat digunakan untuk melakukan operasi dan kegiatan perusahaan (Simatupang, 2019). Untuk mengetahui kegiatan keputusan pendanaan perusahaan, dapat diketahui pada kinerja keuangannya. Maka terkait pengaruh struktur modal pada kinerja keuangan menurut Detthamrong, et al., (2017) dan Marinda, et al., (2014) menyatakan hasil signifikan terkait struktur modal pada kinerja keuangan. Penelitian menurut Nassar (2016) menyatakan hasil signifikan negatif. Sedangkan menurut Fachrudin (2011) dan Simatupang (2019) menyatakan hasil non signifikan.

Struktur modal terdiri dari hutang dan ekuitas, serta menentukan jumlah pembiayaan suatu perusahaan (Waworuntu, et al., 2017). Pembagian hutang dan ekuitas dibuat berdasarkan asumsi, termasuk tidak adanya pajak, biaya transaksi yang dapat diabaikan serta informasi yang beredar di pasar (Tarus \& Ayabei, 2016). Menurut Simatupang (2019), struktur modal menimbulkan manfaat serta resiko pada keuangan suatu perusahaan, saat pemilihan struktur modal tidak tepat. Penelitian ini menjadikan debt to assets ratio (DAR) sebagai rasio struktur modal.

Ada beberapa variabel yang memengaruhi struktur modal, salah satu nya komite audit yang memiliki peranan pada penetapan mekanisme yang membantu untuk menganalisis risiko perusahaan (Waworuntu, et al., 2017). Keberadaan komite audit juga untuk mengawasi hutang yang lebih rendah, agar perusahaan terlindungi terhadap risiko yang disebabkan oleh penggunaan utang. Serta mengawasi penggunaan hutang yang tinggi untuk melindungi minat investor (Tarus \& Ayabei, 2016). Menurut Waworuntu, et al., (2017) terdapat pengaruh signifikan positif terkait komite audit pada struktur modal. Sedangkan menurut Detthamrong, et al., (2017) menyatakan hasil signifikan negatif. Lalu menurut Tarus \& Ayabei (2016) menyatakan hasil non signifikan. 
Salah satu alasan pemilihan sruktur modal sebagai variabel mediasi adalah struktur modal dapat memengaruhi komite audit dalam penyusunan strategi-strategi perusahaan (Simatupang, 2019). Sedangkan, menurut Detthamrong, et al., (2017) komite audit mungkin tidak memiliki efek langsung terhadap kinerja perusahaan. Terdapat salah satu mediator potensial antara komite audit terhadap kinerja keuangan yaitu struktur modal (Detthamrong, et al., 2017). Sehingga, struktur modal diharapkan mampu menjelaskan terkait perubahan komite audit bisa memengaruhi kinerja dalam perusahaan. Sehingga didapatkan riset gap untuk peran mediasi struktur modal pada pengaruh komite audit pada kinerja keuangan seperti hasil penelitian Detthamrong, et al., (2017) yang menyatakan struktur modal mampu memediasi komite audit pada kinerja keuangan, hal ini Simatupang (2019) yakni struktur modal tidak mampu memediasi komite audit pada kinerja keuangan.

Tujuan penelitian ini adalah untuk menganalisis pengaruh ukuran perusahaan, IOS, dividen, komite audit dan struktur modal terhadap kinerja keuangan dan pengaruh komite audit terhadap struktur modal serta menganalisis peran mediasi struktur modal pada komite audit terhadap kinerja keuangan di perusahaan property tahun 2014-2018.

\section{KAJIAN PUSTAKA DAN PENGEMBANGAN HIPOTESIS}

\section{Teori Agency}

Menurut Agency theory, terdapat hubungan kontraktual antara agent dengan principal (Jensen \& Meckling, 1976). Menurut Jensen \& Meckling (1976) principal (pemilik perusahaan) memberikan tanggung jawab terhadap agent untuk mengurus penggunaan dan pengendalian sumber daya terkait penyampaian wewenang saat pengambilan keputusan. Pemilik perusahaan sebagai pemilik saham dapat memberikan perintah pada agent agar melakukan tindakan berdasarkan nama pemilik. Agent adalah pihak yang menerima/ diberi perintah principal (pemilik perusahaan) dalam menjalakan suatu kegiatan perusahaan yang bertujuan memaksimalkan tingkat pengembalian pemegang saham.

Hubungan agency terjadi saat principal memberikan tugas agent terkait pemberian jasa lalu memberikan hak dalam pengambilan keputusan pada agent. Hal ini menjadikan agent mengetahui lebih banyak informasi daripadai principal terkait informasi internal serta prospek perusahaan. Maka dari itu agent berkewajiban sebagai pengelola perusahaan dapat menyampaikan informasi keadaan perusahaan pada principal. Namun, kegiatan ini berpotensi muncul information asymetric (asimetris informasi). Information asymetric adalah ketidaksamaan informasi yang diberikan agent terkait keadaan perusahaan sebenarnya yang disampaikan kepada principal (Jensen \& Meckling, 1976). Saat muncul permasalahan yang terjadi karena konflik kepentingan dan information asymetric maka perusahaan mengalami agency cost (biaya keagenan).

Agency theory dalan penelitian ini menjelaskan pengaruh ukuran perusahaan, IOS, dividen dan komite audit pada kinerja keuangan. Agency theory menyatakan masalah information asymetric dapat diminimalkan melalui penyelarasan kepentingan pada perusahaan dengan melakukan pengawasan pada setiap kegiatan perusahaan. Maka perusahaan dapat menerapkan pengawasan oleh komite audit, pengukuran ukuran perusahaan, perhitungan IOS dan pengawasan dividen. Sehingga dapat meminimalkan agency cost dan konflik kepentingan.

\section{Teori Trade Off}

Menurut trade off theory, perusahaan memilih komposisi atau rancangan utang optimal dalam struktur modal nya untuk memaksimalkan manfaat dari pajak bunga (Modigliani \& Miller, 1963). Lalu menurut Brigham \& Houston (2006:36), melalui tingkat suku bunga dan biaya kebangkrutan, perusahaan dapat melakukan penukaran manfaat pajak dari keuntungan pendanaan melalui utang. Karena bunga adalah pengurang pajak, dapat menyebabkan utang lebih murah dari saham preferen, sehingga dapat diperoleh perlindungan pajak dari utang. Maka, peningkatan laba operasi perusahaan dari penggunaan utang akan diterima oleh investor. 
Tri Indah Sri Mulyaningsih. Analisis Faktor pada Kinerja Keuangan dan Mediasi Struktur Modal pada Komite Audit di Perusahaan Property

Pada kondisi nyatanya, semakin banyak utang maka kewajiban yang harus ditanggung perusahaan semakin besar, karena menimbulkan agency cost, biaya kebangkrutan, keengganan kreditur untuk memberi utang besar (Nassar, 2016). Pada teori ini, tingkat utang yang optimal dapat diperoleh saat penghematan pajak berada pada jumlah yang maksimal terhadap biaya kesulitan keuangan (Detthamrong, et al. 2017). Sehingga, diperoleh keuntungan dan pengorbanan yang seimbang dari penggunaan utang (Nassar, 2016). Teori trade off digunakan pada penelitian ini untuk menguji pengaruh struktur modal (DAR) pada kinerja keuangan (ROA).

\section{Kinerja Keuangan}

Menurut Marinda, et al. (2014), kinerja keuangan menggambarkan bagaimana keberhasilan yang dihasilkan dari kegiatan bisnis suatu perusahaan. Dalam pencapaian kegiatan suatu perusahaan dapat digambarkan dalam laba (profit) yang dihasilkannya, sehingga rasio profitabilitas dapat digunakan untuk menilai kinerja keuangan. Rasio profitabilitas digunakan untuk mengetahui kemampuan suatu perusahaan dalam menghasilkan laba serta menampilkan kemampuan manajemen perusahaan dalam pengelolaan aset secara efektif, sehingga mampu menampilkan proporsi profitabiltas yang baik. Profitabilitas memiliki beberapa proksi yang mewakili, diantaranya ROA, ROE dan NPM. Menurut Pradhan \& Paudel (2017), ROA menunjukkan kemampuan perusahaan untuk mendapatkan laba bersih dari penggunaan aset perusahaan. Return on equity (ROE) menjelaskan berapa banyak laba yang dihasilkan perusahaan dengan setiap ekuitas. Net Profit Margin (NPM) menggambarkan laba bersih yang diperoleh perusahaan terhadap pendapatan.

Pada penelitian ini akan menggunakan ROA, karena ROA menurut penelitian Putra dan Bajra (2015) menampilkan kondisi kinerja keuangan perusahaan dari seluruh aset perusahaan untuk memperoleh laba/ profit. ROA suatu perusahaan yang semakin tinggi menandakan semakin baik nya profit yang diterima oleh perusahaan tersebut. ROA juga memunjukkan kemampuan perusahaan dalam perolehan laba setelah pajak dengan aset yang dimiliki. Rasio ini dapat digunakan pihak manajemen untuk mengevaluasi efektivitas dan efisiensi manajemen perusahaan dalam mengelola seluruh aktiva perusahaan. Berikut beberapa penelitian yang juga menggunakan ROA, Tornyeva \& Wereko (2012), M'rabet \& Boujjat (2016), Kanwal \& Hameed (2017), (Nuzil, 2017), Pervan \& Visic, (2012),Dogan (2013), Putra \& Badjra, (2015), Marinda, et al. (2014), Detthamrong, et al. (2017), dan Simatupang (2019).

Variabel dependen untuk penelitian ini menggunakan kinerja keuangan dengan ROA sebagai proksi yang digunakan. ROA diperoleh dengan menghitung laba komprehensif yang dapat dicari pada laporan laba rugi perusahaan bagian akhir. Kemudian angka tersebut dibagi dengan jumlah aset yang akunnya terletak pada laporan neraca, selanjutnya dikali $100 \%$. Rumus perhitungan ROA menurut Sudana (2015:25) dapat dilihat di rumus (1).

$\mathrm{ROA}=\frac{\text { Earning After Taxes }}{\text { Total Asset }} \times 100 \%$

\section{Struktur Modal}

Menurut Horne \& Wachowicz (2013:176), struktur modal adalah bauran (proporsi) pembiayaan jangka panjang perusahaan yang diwakilkan dengan utang, saham preferen, dan ekuitas saham biasa. Serta menurut Kautsar \& Kusumaningrum (2015) struktur modal digunakan manajer keuangan untuk menentukan penggunaan utang sebagai pendanaan kegiatan perusahaan. Variabel intervening pada penelitian ini akan menggunakan struktur modal dengan proksi debt to asset ratio (DAR). DAR digunakan untuk mengetahui berapa besar aktiva perusahaan yang dibiayai dengan hutang (Kautsar \& Kusumaningrum, 2015). Semakin tinggi rasio DAR suatu perusahaan, semakin tinggi risiko ketidakmampuan perusahaan melunasi seluruh hutangnya (Purwohandoko, et al. 2014:53). Selain DAR, struktur modal juga dapat diperhitungkan dengan debt to equity ratio (DER). DER digunakan untuk mengetahui berapa jumlah total modal yang dibiayai oleh total hutang (Fachrudin, 2011). Pada penelitian ini akan menggunakan DAR, karena aset lebih mencerminkan kestabilan perusahaan ketimbang ekuitas. Selain itu terdapat beberapa penelitian yang juga menggunakan DAR,yaitu Detthamrong, et al., (2017) dan Marinda, et al., (2014). DAR diperoleh dari jumlah liabilitas/utang 
yang kemudian dibagi dengan jumlah aset/ aktiva pada akun laporan neraca kemudian dikali $100 \%$. Rumus perhitungan DAR menurut Purwohandoko, et al. (2014:53) dapat dilihat di rumus (2).

DAR $=\frac{\text { Total Utang }}{\text { Total Aktiva }} \times 100 \%$

\section{Komite Audit}

Komite audit merupakan sub-komite direktur yang berwenang secara independen pada penyusunan kinerja keuangan serta pengungkapan yang akurat sesuai standar pelaporan (Detthamrong, et al., 2017). Untuk memastikan independensi komite audit, komite harus terdiri dari hanya direktur non eksekutif dan dengan keanggotaan tidak kurang dari tiga anggota (Tornyeva \& Wereko, 2012). Jumlah anggota komite audit dapat diketahui di annual report pada bagian profil manajemen perusahaan. Rumus perhitungan komite audit menurut Detthamrong, et al. (2017) dapat dilihat di rumus (3).

Komite audit $=$ Total Angka Jumlah Komite Audit

\section{Ukuran Perusahaan}

Menurut Putra \& Badjra (2015) ukuran perusahaan memberikan makna besar atau kecil nya kelayakan suatu perusahaan dalam memperoleh tambahan modal eskternal dan profitabilitas. Untuk ukuran perusahaan yang besar akan mempermudahkannya memperoleh modal eksternal dan meningkatkan profitabilitas melalui peningkatkan produktivitas perusahaan. Dalam pengukuran ukuran perusahaan terdapat beberapa proksi yang mewakili, diantaranya total aset, total penjualan dan jumlah pekerja. Pada penelitian ini akan menggunakan total aset. Karena total aset menurut Dogan (2013) memiliki hubungan positif stabil dan dapat meningkatkan profitabilitas perusahaan dibandingkan total penjualan dan jumlah pekerja. Selain itu, terdapat beberapa penelitian yang menggunakan total aset, yaitu Pervan \& Visic (2012) dan Dogan (2013). Ukuran perusahaan dapat diketahui dengan menjumlahkan total aset perusahaan dengan natural logaritma. Natural logaritma digunakan untuk mengkonversi angka total aset ke nominal yang lebih kecil dan terdistribusi secara normal (Kautsar, 2014). Total aset dapat diketahui melalui laporan neraca pada akun total aset, dengan perhitungan menurut Detthamrong, et al., (2017) dapat dilihat di rumus (4).

Ukuran Perusahaan $=$ Ln Total Aset

\section{IOS (investment opportunity set)}

Menurut Myers (1977) Investment Opportunity Set (IOS) adalah keputusan investasi dari hasil perpaduan aktiva yang dimiliki atau asset in place dengan pilihan investasi yang memiliki net present value positif. IOS mampu mengetahui peluang investasi yang terjadi di perusahaan. Peluang ini dapat diilustrasikan jika semakin besar dividen yang diberikan maka peluang investasi semakin kecil, karena laba ditahan perusahaan akan semakin kecil. Dengan semakin kecil nya laba ditahan, dapat menyebabkan prospek bisnis dan kualitas keuangan perusahaan menjadi diragukan.

IOS memiliki beberapa proksi yang dapat digunakan, diantaranya MBVA (the market value of assets to book value of assets ratio), MBVE (the market to book value of equity ratio), dan PPEMVA (property and equipmen to market value of firm). Pada penelitian ini akan menggunakan MBVA. Karena menurut Adam \& Goyal (2008) MBVA memiliki informasi tertinggi sehubungan dengan peluang investasi memiliki informasi. Selain itu penelitian sejenis yang dilakukan oleh M. Hutchinson \& Gul (2004) dan Yuliani, et al. (2018) juga menggunakan MBVA. Penelitian ini menggunakan proksi MBVA, dimana total aset dikurangi dengan total ekuitas yang dapat diketahui pada laporan neraca. Kemudian menambahkan share outstanding (jumlah saham beredar) yang diperoleh pada ikhtisar saham annual report pada bagian jumlah saham beredar, lalu dikalikan dengan share closing price (harga saham penutupan) yang dapat dilihat pada ikhtisar saham pada bagian harga penutupan. Setelah itu dibagi dengan total aset. The market value of assets to book values of assets ratio (MBVA) dengan perhitungan menurut Hutchinson \& Gul (2004) dapat dilihat di rumus (5). 
Tri Indah Sri Mulyaningsih. Analisis Faktor pada Kinerja Keuangan dan Mediasi Struktur Modal pada Komite Audit di Perusahaan Property

$\mathrm{MBVA}=\frac{(\text { total aset }- \text { total equity })+(\text { share outstanding } X \text { share closing price }}{\text { total asset }}$

Dividen

Menurut Kautsar (2019) dividen merupakan pendapatan atau keuntungan perusahaan yang dibayarkan ke pemegang saham. Pendapatan perusahaan dapat disalurkan untuk pembayaran atau dipertahankan sebagai laba ditahan untuk investasi di perusahaan (Tornyeva \& Wereko, 2012). Perusahaan yang melakukan pembagian dividen, akan merasakan dampak pada laba ditahannya (Kautsar, 2014). Kemampuan perusahaan untuk membayar dividen dari laba ditaham dapat digunakan investor untuk memperoleh informasi mengenai pertumbuhan dan kinerja keuangan perusahaan (Kautsar, 2019).

Dalam dividen terdapat beberapa proksi yang mewakili, diantaranya dividen saham dan dividen tunai. Menurut M, Waren, \& Carl, (2010) dividen saham meruapakan pembagian lembar saham kepada para pemegang saham. Dividen tunai merupakan pembagian keuntungan secara tunai oleh perseroan kepada para pemegang saham. Pada penelitian ini akan menggunakan dividen tunai dengan proksi DPR atau dividend payout ratio. Karena DPR memacu kinerja saham di bursa efek, yang merupakan return dari pemegang saham. DPR dapat dijadikan persediaan dana melalui penerbitan utama saham ekuitas dan saham akan secara aktif diperdagangkan di bursa saham dan meningkatkan kinerja perusahaan di pasar (Tornyeva \& Wereko, 2012). Terdapat penelitian sejenis yang menggunakan DPR, yaitu penelitian Kanwal \& Hameed (2017) dan Nuzil (2017). Penelitian ini menggunakan proksi DPR yang diperoleh dengan menghitung dividend per share yang terdapat pada kebijakan dividen atau pembagian dividen annual report, lalu dibagi dengan earning per share, yang dapat diperoleh dari laporan laba rugi perusahaan. DPR dihitung dengan menggunakan perhitungan menurut Kautsar (2019) dapat dilihat di rumus (6).

$\mathrm{DPR}=\frac{\text { Dividend Per Share }}{\text { Earning Per Share }}$

\section{Hubungan antar Variabel}

Penlitian Pervan \& Visic (2012) dan (Dogan, 2013) menyatakan terdapat pengaruh siginifikan positif antara ukuran perusahaan pada kinerja keuangan.Seperti yang disampaikan oleh Dogan (2013) ukuran perusahaan dapat menandakan keefektifan perusahaan. Dengan semakin besarnya ukuran perusahaan yang mampu meningkatkan likuiditas perusahaan serta meningkatkan profitabilitas aset perusahaan. Menurut Pervan \& Visic (2012) saat profitabilitas perusahaan naik, rasio perputaran aset juga naik, yang menunjukkan efektifitas manajemen dalam pencapaian kinerja perusahaan yang lebih baik.

Pengaruh positif penelitian ini sesuai dengan agency theory. Pada ukuran perusahaan terdapat penilaian besar-kecil nya suatu perusahaan, dimana terdapat interaksi principal dengan agent. Interaksi ini terjadi untuk meningkatkan ukuran perusahaan agar lebih efektif memperoleh laba bagi suatu perusahaan (Dogan, 2013).

H1: Ada pengaruh ukuran perusahaan terhadap kinerja keuangan.

Penelitian Sanjabi \& Jamshidinavid (2017) memberikan hasil positif signifikan antara IOS dengan kinerja keuangan. Menurut Myers (1977) Investment opportunity set (IOS) adalah keputusan investasi dari hasil perpaduan aktiva yang dimiliki atau asset in place dengan pilihan investasi yang memiliki net present value positif. Dengan adanya agency theory, para princiipal dapat melakukan penilaian baik atau buruk nya investasi pada perusahaan tersebut melalui agent. Menurut Sanjabi \& Jamshidinavid (2017) Sebelum berinvestasi, calon investor harus memiliki desain. Total desain harus mencakup keputusan relatif transaksi, metode kepemilikan, durasi umur aset, dan jumlah profitabilitasnya. Proses pengungkapan peluang investasi membutuhkan pengalaman dan analisis sifat sebenarnya dari keputusan investasi.

H2: Ada pengaruh IOS terhadap kinerja keuangan. 
Penelitian Tornyeva \& Wereko (2012), M'rabet \& Boujjat (2016) dan Kanwal \& Hameed (2017) memberikan hasil positif signifikan antara dividen dengan kinerja keuangan. Kebijakan dividen perusahaan memberikan informasi bagaimana laba akan disesuaikan ketika diumumkan. Pendapatan perusahaan dapat disalurkan untuk pembayaran atau dipertahankan sebagai laba ditahan untuk investasi di perusahaan (Tornyeva \& Wereko, 2012). Perusahaan yang melakukan pembagian dividen, akan berdampak pada laba ditahan. Akan tetapi, dengan membagikan dividen, dapat mengurangi agency cost (Nuzil, 2017).

Agency theory menyarankan bahwa, kebijakan dividen ditentukan oleh agency cost yang timbul dari divergensi kepemilikan dan kontrol. Agent mungkin tidak selalu melakukan kebijakan dividen yang memaksimalkan nilai untuk pemegang saham tetapi akan memilih kebijakan dividen yang memaksimalkan keuntungan perusahaan. Pengaruh signifikan positif menurut Tornyeva \& Wereko (2012) dan Kanwal \& Hameed (2017), pembayaran dividen akan menarik minat investor sehingga dapat meningkatkan kinerja keuangan perusahaan. Lalu menurut M'rabet \& Boujjat (2016) (2016) investasi dibiayai dari sumber eksternal dengan biaya modal, dengan demikian mendorong kinerja perusahaan untuk memperoleh keuntungan.

H3: Ada pengaruh dividen terhadap kinerja keuangan.

Penelitian Tornyeva \& Wereko (2012) memberikan hasil positif signifikan antara komite audit dengan kinerja keuangan. Komite audit merupakan sub-komite diektur yang memiliki wewenang independen dengan sistem kontrol internal dan standar audit, pada penyusunan laporan keuangan (Detthamrong, et al., 2017). Pengawasan yang dilakukan komite audit dapat meminimalkan agency cost yang terdapat pada agency theory. Hal ini dikarenakan kepercayaan principal pada agent untuk mengolah aset yang dimiliki principal. Serta, asymetric information dapat diatasi dengan pengawasan saat menyelaraskan beragam kepentingaan pada perusahaan. Menurut Tornyeva \& Wereko (2012) komite audit bertanggungjawab terhadap kinerja keuangan dan memastikan integritas kinerja keuangan dan meningkatkan transparansi. Sehingga dapat meminimalkan agency cost dan information asymetric.

H4: Ada pengaruh komite audit terhadap kinerja keuangan.

Penelitian Detthamrong, et al., (2017) dan Marinda, et al., (2014) memberikan hasil positif signifikan antara struktur modal dengan kinerja keuangan. Struktur modal merupakan proporsi dana untuk memenuhi kebutuhan perusahaan. Dana yang dimaksud dapat bersumber dari pendanaan internal dan pendanaan eksternal (utang). Struktur modal ini diproksikan dengan DAR (Debt to Asset Ratio) yang merupakan pengukuran jumlah aktiva perusahaan yang dibiayai oleh utang atau modal (Marinda, et al., 2014).

Berdasarkan trade off theory, perusahaan memilih komposisi utang optimal dalam struktur modal mereka untuk memaksimalkan manfaat dari pajak bunga. Sehingga, diperoleh proporsi yang seimbang antara manfaat dengan pengorbanan yang timbul akibat penggunaan utang dan modal pada kinerja keuangan perusahaan. Menurut Detthamrong, et al., 2017) kreditor dapat memonitor kinerja keuangan lebih baik daripada pemegang saham luar, melalui struktur modal. Serta menurut Marinda, et al., (2014) hubungan positif menandakan bahwa semakin tinggi struktur modal debt asset ratio (DAR) maka kinerja keuangan return on asset (ROA) akan semakin tinggi juga. Dengan penggunaan struktur modal dapat menjelaskan bagaimana perusahaan menggunakan utang atau dana sendiri untuk meningkatkan kinerja perusahaannya.

H5: Ada pengaruh struktur modal terhadap kinerja keuangan.

Penelitian Waworuntu, et al., (2017) memberikan hasil positif signifikan antara komite audit dengan struktur modal. Menurut trade off theory, para manajer perusahaan mungkin berusaha mencari keuntungan melalui leverage dan dapat menggunakannya secara ilegal dengan membebankan kepada pemegang saham. Hal ini dapat terjadi karena manajer sering membuat keputusan sendiri atas 
Tri Indah Sri Mulyaningsih. Analisis Faktor pada Kinerja Keuangan dan Mediasi Struktur Modal pada Komite Audit di Perusahaan Property

kepentingan pribadi, yang dapat membawa ke masalah agensi. Manajer atau agent seharusnya bertindak untuk kepentingan terbaik pemegang saham, karen pemegang saham mempercayakan kontrol kepada agent. Hal ini juga dapat disebabkan oleh information asymetric, dimana agent mengetahu lebih banyak informasi tentang perusahaan daripada pemegang saham. Menurut Waworuntu, et al., (2017) komite audit melaksanakan tugas nya dalam pengawasan struktur modal perusahaan. Sehingga, dapat meminimalkan agent untuk mencari keuntungan sendiri dan nformation asymetric antara agent dengan principal atau pemilik saham.

H6: Ada pengaruh komite audit terhadap struktur modal.

Menurut penelitian Detthamrong, et al., (2017) memberikan hasil struktur modal mampu menjadi mediasi komite audit pada kinerja keuangan. Struktur modal dapat digunakan untuk memahami terkait perubahan pada komite audit dapat memengaruhi kinerja perusahaan.Perusahaan perlu menetapkan sumber pendanaan dalam struktur modal secara optimal untuk meningkatkan keberhasilan kinerja perusahaan. Melalui komite audit, masalah keagenan dapat teratasi sehingga manajemen dapat menentukan perimbangan sumber pendanaan perusahaan tanpa mementingkan kepentingan pihak tertentu. Menurut Detthamrong, et al., (2017) komite audit dapat membuat perusahaan mendapatkan akses yang lebih baik untuk pendanaan eksternal.

Berdasarkan agency theory, terdapat dua pihak (agent dan principal) yang menyebabkan timbulnya masalah-masalah keagenan sehingga diperlukannya suatu mekanisme yang dapat menyelaraskan kepentingn-kepentingn yang berbeda di antara kedua pihak tersebut. Struktur modal yang diproksikan dengan indikator DAR dapat menyelaraskan kepentingan pihak investor dan manajemen serta mengurangi agency cost melalui pengawasan yang dilakukan oleh kreditur yang memberikan pinjaman kepada perusahaan. Perusahaan melakukan kontrol mulai dari kegiatan operasional hingga kondisi keuangan perusahaan, yang dapat diamati melalui struktur modal. Ketika kebijakan manajemen terhadap struktur modal telah optimal, maka kinerja keuangan perusahaan yang lebih baik akan mudah diperoleh (Simatupang, 2019)

H7: Ada pengaruh mediasi struktur modal pada komite audit terhadap kinerja keuangan.

\section{METODE PENELITIAN}

Konklusif-kausal dipilih sebagai jenis penelitian ini, karena penelitian ini menguji hubungan sebab akibat beberapa variabel yakni variabel independen yaitu ukuran perusahaan, IOS, dividen, komite audit lalu kinerja keuangan sebagai variabel dependen dan struktur modal sebagai variabel intervening. Teknik pengumpulan data menggunakan teknik dokumentasi. Jenis data pada penelitian ini yaitu data sekunder berupa laporan tahunan perusahaan property yang terdaftar di Indonesia Stock Exchange tahun 2014-2018. Data tersebut bersumber dari website resmi Indonesia Stock Exchange (www.idx.co.id). Populasi yang digunakan adalah 56 perusahaan pada sektor property yang terdaftar di IDX tahun 2014-2018. Pada penelitian ini, teknik purposive sampling digunakan untuk memperoleh sampel. Kriteria sampel pada penelitian ini adalah (1) perusahaan sektor property yang terdaftar pada idx.co.id periode 2014-2018, (2) perusahaan yang tidak mengeluarkan laporan keuangan secara lengkap periode 2014-2018, (3) perusahaan yang tidak memiliki profitabilitas ROA positif periode 2014-2018. Jumlah sampel yang diperoleh sebanyak 28 perusahaan dan periode penelitian mulai 2014 sampai 2018. Teknik analisis data menggunakan teknik analisis jalur (path analysis) dengan menggunakan alat analisis IBM SPSS Statistics versi 20.

\section{HASIL DAN PEMBAHASAN}

\section{Hasil Data Screening}

Terdapat beberapa uji yang dilakukan pada penelitian ini,seperti uji normalitas,transformasi data dan data outlier. Untuk pengujian normalitas data, dari hasil data yang telah dilakukan menunjukkan 1 variabel yang memiliki nilai signifikan $>0,05$ yaitu variabel struktur modal. Terdapat 5 variabel berdistribusi tidak normal yang memiliki nilai signifikan $<0,05$. Sehingga, diperlukan transformasi 
data agar menjadi data yang normal (Ghozali, 2016:31). Hasil transformasi data, berdasarkan hasil test statistik K-S untuk variabel yang sudah ditransformasikanm diperoleh 3 variabel yang terdistribusi normal, yaitu SQRT KinerjaKeuangan, LnIOS, dan LnDiv. Variabel ukuran perusahaan dan komite audit tidak mnengalami transformasi data. Data outlier dilakukan setelah proses transformasi data untuk mendapatkan data yang normal. Berdasarkan hasil pengujian, tidak ditemukan data outlier.

\section{Uji Asumsi Klasik}

Dapat diketahui pada tabel 1. Pada uji multikolinieritas tidak terjadi multikolineritas, karena variabel independen memiliki nilai tolerance $>0,10$ dan VIF $<10$. Pada uji autokorelasi, juga tidak terjadi autokorelasi karena dengan run test diperoleh hasil $>0,05$. Pada uji heteroskedastisitas, juga tidak terjadi heteroskedastisitas dengan menggunakan uji glejser diperoleh hasil signifikansi seluruh variabel independen $>0,05$. Pada uji normalitas K-S, data residual memiliki distribusi normal karena nilai signifikansi $>0,05$. Pada uji linearitas, tidak terjadi linearitas karena dengan uji langrange multiplier diperoleh nilai $c^{2}$ tabel $(168,613)>c^{2}(99,82)$ hitung dengan signifikansi 0,05 .

Tabel 1.

\section{UJI ASUMSI KLASIK}

\begin{tabular}{llc}
\hline & Jenis Uji & Hasil \\
\hline Multikolinieritas & Ukuran perusahaan (Tolerance) &, 652 \\
& Komite Audit (Tolerance) &, 755 \\
& Struktur Modal (Tolerance) &, 863 \\
& LnIOS (Tolerance) &, 586 \\
& LnDividen (Tolerance) &, 813 \\
& Ukuran perusahaan (VIF) & 1,534 \\
& Komite audit (VIF) & 1,324 \\
& Struktur modal (VIF) & 1,158 \\
& LnIOS (VIF) & 1,705 \\
Autokorelasi & LnDividen (VIF) & 1,230 \\
Normalitas & Run Test &, 830 \\
Heteroskesdasisitas &, 998 \\
Linearitas & Uji K-S & $>0,05$ \\
\hline Sumber: Hasil Glejser & Uji Lagrange Multiplier & $99,82<168,613$ \\
\hline
\end{tabular}

\section{Hasil Uji Koefisien Determinasi (Adjusted $\boldsymbol{R}^{2}$ )}

Dapat diketahui dari tabel 2 nilai Adjusted $R^{2}$ sebesar 69,6\% variabel kinerja keuangan dipengaruhi oleh ukuran perusahaan, IOS, dividen, komite audit, dan struktur modal. Sisanya sebesar 30,4\% dijelaskan oleh variabel lain di luar penelitian ini.

\section{Hasil Uji Signifikan Simultan (Uji F)}

Dapat diketahui dari tabel 2 nilai $F$ hitung sebesar, $000^{\mathrm{b}}$ lebih kecil dari 0,05. Sehingga dapat diketahui variabel independen yaitu ukuran perusahaan, IOS, dividen, komite audit, dan struktur modal secara bersama-sama berpengaruh terhadap variabel dependen yaitu kinerja keuangan (ROA).

\section{Hasil Uji Signifikansi Parameter Individual (Uji t) dan Uji Signifikansi Analisis Jalur}

Dapat diketahu pada uji t tabel 3 ukuran perusahaan, struktur modal dan dividen memiliki pengaruh signifikan negatif terhadap kinerja keuangan. IOS berpengaruh signifikan positif terhadap kinerja keuangan. Komite audit tidak berpengaruh signifikan terhadap kinerja keuangan. Pada tabel 3 dapat diketahui komite audit tidak berpengaruh signifikan terhadap struktur modal [b(MX)]. Pengaruh mediasi struktur modal pada komite audit terhadap kinerja keuangan juga tidak berpengaruh signifikan atau tidak mampu memediasi [b(YM.X)]. 
Tri Indah Sri Mulyaningsih. Analisis Faktor pada Kinerja Keuangan dan Mediasi Struktur Modal pada Komite Audit di Perusahaan Property

Berdasarkan tabel 2 diperoleh perumusan model persamaan linier berganda (7).

Sqrt Kinerja Keuangan $=-0,005$ Ukuran perusahaan $+0,103 \operatorname{LnIOS}-0,026 \operatorname{LnDividen}-$ 0,256 Struktur modal $+\mathrm{e}$

Nilai koefisien regresi ukuran perusahaan, IOS, dividen, komite audit dan struktur modal menandakan perubahan variabel-variabel ini akan menyebabkan naik turunnya nilai kinerja keuangan (ROA). Nilai koefisien dapat dilihat pada rumus (8)

$\mathrm{B}=-0,005$ Ukuran perusahaan $+0,103$ LnIOS $-0,026$ LnDividen $-0,256$ Struktur modal

\section{Tabel 2. UJI HIPOTESIS}

\begin{tabular}{|c|c|c|c|c|}
\hline & B & $\mathrm{T}$ & Sig. & Keterangan \\
\hline Adjusted $\mathrm{R}^{2}$ & & & ,696 & \\
\hline Uji F & & &, $000^{\mathrm{b}}$ & Berpengaruh \\
\hline $\begin{array}{ll}\text { Uji } & \text { t } \\
\text { (constant) }\end{array}$ & ,466 & 7,320 & ,000 & \\
\hline $\begin{array}{l}\text { Ukuran } \\
\text { perusahaan }\end{array}$ &,- 005 & $-2,892$ & ,005 & Signifikan Negatif \\
\hline Komite Audit &,- 012 &,- 898 & ,372 & Non Signifikan \\
\hline $\begin{array}{l}\text { Struktur } \\
\text { Modal }\end{array}$ &,- 256 & $-6,764$ & , 000 & Signifikan Negatif \\
\hline LnIOS & ,103 & 9,410 & ,000 & Signifikan Positif \\
\hline LnDividen &,- 029 & $-5,917$ & ,000 & Signifikan Negatif \\
\hline
\end{tabular}

Sumber : Hasil SPSS, data diolah 2020

Tabel 3.

UJI SIGNIFIKANSI ANALISIS JALUR

\begin{tabular}{|c|c|c|c|c|c|}
\hline & Keterangan & $\begin{array}{l}\text { Unstanda } \\
\text { rdized } \\
\text { Beta }\end{array}$ & $\begin{array}{l}\text { Varia } \\
\text { nce }\end{array}$ & $\begin{array}{l}\mathrm{Sig} \\
\text { (two) }\end{array}$ & Hasil \\
\hline P1 & $\begin{array}{l}\text { Nilai jalur komite audit } \\
\text { terhadap kinerja keuangan }\end{array}$ & ,028 & & & \\
\hline P2 & $\begin{array}{l}\text { Nilai jalur komite audit } \\
\text { terhadap struktur modal }\end{array}$ & ,068 & & & \\
\hline P3 & $\begin{array}{l}\text { Nilai jalur struktur modal } \\
\text { terhadap kinerja keuangan }\end{array}$ &,- 011 & & & \\
\hline E1 & $\begin{array}{l}\text { Jumlah variance variabel } \\
\text { struktur modal yang tidak } \\
\text { dijelaskan oleh komite audit }\end{array}$ & & 991 & & \\
\hline E2 & $\begin{array}{l}\text { Jumlah variance kinerja } \\
\text { keuangan yang tidak dapat } \\
\text { dijelaskan oleh komite audit } \\
\text { dan kinerja keuangan }\end{array}$ & & 996 & & \\
\hline $\begin{array}{l}b(\mathrm{MX} \\
)\end{array}$ & $\begin{array}{l}\text { Komite audit terhadap struktur } \\
\text { modal }\end{array}$ & & & 0,1239 & $\begin{array}{c}\text { Non } \\
\text { Signifikan }\end{array}$ \\
\hline $\begin{array}{l}\mathrm{b}(\mathrm{YM} \\
. \mathrm{X})\end{array}$ & $\begin{array}{l}\text { Peran mediasi struktur modal } \\
\text { pada komite audit terhadap } \\
\text { kinerja keuangan }\end{array}$ & & & 0,8704 & $\begin{array}{c}\text { Non } \\
\text { Signifikan }\end{array}$ \\
\hline
\end{tabular}

Sumber : Hasil SPSS, data diolah 2020

\section{Pengaruh IOS terhadap Kinerja Keuangan}

IOS terhadap kinerja keuangan memberikan hasil positif signifikan. Maksud dari arah hubungan positif adalah semakin besar IOS akan meningkatkan kinerja keuangan. Penelitian ini sejalan dengan penelitian terdahulu yang dilakukan oleh Sanjabi \& Jamshidinavid (2017). Hasil penelitian ini dapat 
terjadi karena, semakin tinggi IOS (investment opportunity set) yang diproksikan dengan MBVA (market value of assets to book values of assets ratio) semakin tinggi keputusan investasi yang diperoleh perusahaan dari investor. Dengan hal tersebut, keputusan investasi yang diterima perusahaan dapat meningkatkan potensi pengembangan pasar terhadap perusahaan, yang mampu memberikan laba yang lebih besar bagi perusahaan dengan bertambahnya investor.

Dapat diketahui untuk implikasi teoritis dari penelitian ini sesuai seperti teori agency. Karena melalui agency theory, principal melalui agent dapat bertugas melakukan penilaian baik atau buruk nya investasi pada perusahaan. Untuk implikasi praktis dari hasil penelitian ini adalah perusahaan sektor property dapat memperhatikan peningkatan nilai IOS yang diproksikan dengan MBVA, saat nilai IOS naik maka kinerja keuangan juga meningkat. Upaya peningkatan IOS dapat dilakukan dengan meningkatkan kombinasi antara aktiva yang dimiliki dan pilihan investasi yang akan datang dengan NPV positif.

\section{Pengaruh Dividen terhadap Kinerja Keuangan}

Dividen memberikan hasil signifikan negatif terhadap kinerja keuangan. Maksud dari arah hubungan negatif adalah semakin tinggi dividen (DPR) yang dibagikan maka kinerja keuangan perusahaan akan semakin menurun. Penelitian ini sesuai dengan penelitian yang telah dilakukan oleh $\mathrm{K}$ \& Akash (2018). Pengaruh signifikan negatif dari penelitian yang dilakukan ini terjadi karena, semakin tinggi jumlah dividen dengan proksi DPR (dividend payout ratio) semakin tinggi pembagian keuntungan secara tunai oleh perusahaan pada pemegang saham. Kemungkinan yang dapat memengaruhi menurunnya nilai kinerja keuangan (ROA) karena laba yang ditahan perusahaan akan semakin kecil. Dengan semakin kecilnya laba ditahan, dapat menyebabkan kinerja keuangan perusahaan menjadi diragukan.

Dapat diketahui implikasi teoritis dari penelitian ini tidak sama seperti teori agency yang menyatakan, agent akan memilih kebijakan dividen yang memaksimalkan keuntungan perusahaan.Untuk implikasi praktis bagi perusahaan sektor property dari penelitian ini adalah jumlah dividen yang semakin banyak dibagikan akan menurunkan kinerja keuangan. Sehingga, perusahaan dapat meningkatkan kinerja keuangan dengan melakukan laba ditahan daripada pembagian dividen, karena laba diatahan dapat digunakan untuk pengembangan perusahaan.

\section{Pengaruh Komite Audit terhadap Kinerja Keuangan}

Komite audit tidak memiliki pengaruh terhadap kinerja keuangan. Penelitian ini sama dengan penelitian terdahulu yang dilakukan oleh Olayinka (2019). Tidak ada pengaruh dari komite audit ke kinerja keuangan ini dapat terjadi karena jumlah anggota komite audit bukan menjadi dasar yang dapat digunakan untuk mengukur kinerja keuangan perusahaan. Dalam hal ini, jumlah komite audit yang kecil belum tentu memiliki nilai kinerja keuangan yang kecil. Dapat diketahui untuk implikasi teoritis dari penelitian tidak sama dengan teori agency. Karena, pada teori agency,principal memberikan tugas kepada agent (komite audit) untuk mengawasi perusahaan, agent diharapkan mampu memberikan kontrol, kendali dan peningkatan pada pelaksanaan kinerja keuangan perusahaan. Sedangkan pada hasil yang ditemukan penelitian ini, komite audit tidak berpengaruh terhadap kinerja keuangan perusahaan. Untuk implikasi praktis dari hasil penelitian yang telah dilakukan, perusahaan sektor property tidak perlu meningkatkan jumlah komite audit karena naiknya jumlah komite audit tidak memberikan pengaruh pada kinerja keuangan. Upaya yang dapat dilakukan oleh perusahaan adalah dengan meningkatkan fungsi dan tugas komite audit, agar pengawasan dan pertimbangan kebijakan lebih menguntungkan perusahaan.

\section{Pengaruh Struktur Modal terhadap Kinerja Keuangan}

Struktur modal terhadap kinerja keuangan memiliki pengaruh signifikan negatif. Arah hubungan negatif ini menjelaskan semakin besar struktur modal maka akan semakin menurunkan kinerja keuangan. Penelitian ini sejalan dengan penelitian terdahulu yang dilakukan oleh Nassar (2016). Hasil penelitian ini dapat terjadi karena penggunanaan struktur modal dengan proksi DAR (debt to assets 
ratio) tidak slelau berdampak positif terhadap kinerja keuangan. Pada karakteristik perusahaan sektor property yang memproduksi produk jangka panjang berpotensi untuk hutang pada bank, maka sebaiknya perusahaan property menghindari penambahan hutang. Tujuan untuk menghindari penambahan hutang adalah meminimalkan penurunan pendapatan perusahaan, karena hutang akan mengakibatkan beban bunga yang tinggi pada pendapatan.

Dapat diketahui implikasi teoritis dari penelitian ini tidak sama seperti teori trade off. Pada teori trade off, menyatakan tujuan peningkatkan kinerja keuangan dengan menambah keuntungan perusahaan karena nilai hutang, dimana penghematan pajak dapat digunakan untuk keuntungan perusahaan. Implikasi praktis bagi perusahaan sektor property dari penelitian ini adalah struktur modal hutang yang diproksikan dengan DAR memberikan dampak penurunan kinerja keuangan perusahaan. Maka dari itu, perusahaan sektor property lebih baik meminimalkan uang perusahaan dengan memaksimalkan manfaat ekuitas dan sumber daya yang dimiliki perusahaan tersebut.

\section{Pengaruh Komite Audit terhadap Struktur Modal}

Terdapat variabel dependen kedua akibat adanya analisis jalur, yaitu struktur modal dengan komite audit sebagai variabel independennya. Komite audit tidak memiliki pengaruh terhadap struktur modal. Banyak atau sedikitnya jumlah anggota komite audit tidak memengaruhi struktur modal. Terdapat penelitian terdahulu yang sesuai yaitu penelitian Tarus dan Ayabei (2016). Hasil penelitian ini dapat terjadi karena jumlah anggota komite audit tidak menjadi landasan yang digunakan untuk menilai struktur modal perusahaan. Dalam hal ini, perusahaan yang memiliki jumlah komite audit yang kecil belum tentu memiliki nilai struktur modal yang kecil pula.

Dapat diketahui untuk implikasi teoritis dari penelitian ini tidak sesuai dengan teori trade off, yang menyatakan komite audit melaksanakan tugasnya dalam pengawasan struktur modal perusahaan, dalam pemanfaatan hutang sebagai komposisi yang seimbang untuk struktur modal. Untuk implikasi praktis dari penelitian ini ialah perusahaan sektor property tidak perlu meningkatkan jumlah komite audit karena naiknya jumlah komite audit tidak akan memengaruhi struktur modal. Upaya yang dapat dilakukan oleh perusahaan adalah dengan meningkatkan fungsi dan tugas, sehingga pengawasan serta pertimbangan kebijakan lebih efisien dalam penentuan komposisi struktur modal perusahaan.

\section{Pengaruh Mediasi Struktur Modal Pada Komite Audit terhadap Kinerja Keuangan}

Struktur modal tidak mampu memediasi komite audit terhadap kinerja keuangan. Ketidakmampuan struktur modal dalam memediasi sesuai dengan hasil penelitian Simatupang (2019). Kegagalan mediasi ini dapat terjadi karena secara parsial jumlah komite audit pada kinerja keuangan dan struktur modal tidak terdapat pengaruh atau non signifikan. Sedangkan struktur modal berpengaruh terhadap kinerja keuangan tetapi memiliki arah yang negatif karena perusahaan-perusahaan sektor property cenderung melakukan hutang di bank, alangkah lebih baik perusahaan sektor property sebaiknya menghindari penambahan hutang yang berdampak pada beban bunga yang tinggi, sehingga menurunkan kinerja keuangan perusahaan

Dapat diketahui untuk implikasi teoritias yang ditemukan ialah penelitian ini tidak sesuai dengan teori agency dan teori trade off yang menyatakan bahwa melalui komite audit, masalah keagenan dapat teratasi sehingga manajemen dapat menentukan perimbangan sumber pendanaan perusahaan tanpa mementingkan kepentingan pihak tertentu. Komite audit diharapkan mampu membuat perusahaan mendapatkan akses yang lebih baik untuk pendanaan eksternal. Berdasarkan agency theory, terdapat dua pihak (agent dan principal) yang menyebabkan timbulnya masalah-masalah keagenan sehingga diperlukannya suatu mekanisme yang dapat menyelaraskan kepentingn-kepentingn yang berbeda di antara kedua pihak tersebut. Struktur modal yang diproksikan dengan indikator DAR pada hasil penelitian tidak mampu menyelaraskan kepentingan pihak investor dan manajemen serta mengurangi agency cost melalui pengawasan yang dilakukan oleh kreditur yang memberikan pinjaman kepada perusahaan. Sehingga, pada hasil penelitian ini, perusahaan tidak mampu melakukan kontrol mulai dari kegiatan operasional hingga kondisi keuangan perusahaan, melalui struktur modal 


\section{KESIMPULAN}

Hasil penelitian variabel IOS terhadap kinerja keuangan memberikan hasil signifikan positif. Namun, ukuran perusahaan, dividen (DPR) dan struktur modal (DAR) dengan kinerja keuangan memberikan hasil signifikan negatif. Untuk variabel komite audit, memberikan hasil non signifikan terhadap kinerja keuangan dan struktur modal. Penelitian ini dilakukan sebagai penyelesaian fenomena atau permasalahan yang ada pada perusahaan sektor property yang memiliki penurunan rata-rata ROA konsisten pada tahun 2014-2018. Fenomena ini menggunakan pendekatan dua teori, yaitu teori agency dan teori trade off. Fenomena yang terjadi pada sektor property tahun 2014-2018 ini dapat diatasi melalui kontrol total aset perusahaan, peningkatan nilai IOS, penambahan laba ditahan, dan menurunkan hutang perusahaan agar nilai kinerja keuangan (ROA) perusahaan semakin baik. Serta perusahaan tidak perlu memperhatikan jumlah komite audit karena tidak memengaruhi kinerja keuangan (ROA) serta struktur modal (DAR). Keterbatasan pada penelitian terdapat pada data yang tersedia, karena masih terdapat perusahaan property yang tidak menerbitkan laporan tahunan secara lengkap pada periode 2014-2018. Penelitian selanjutnya dapat menggunakan variabel lain atau proksi lain untuk memengaruhi kinerja keuangan seperti ukuran perusahaan dapat menggunakan proksi total penjualan/ total karyawan, IOS dengan proksi MBVE/PPEMVA, pembagian dividen saham atau keputusan laba ditahan, kualitas komite audit, dan struktur modal yang diproksikan dengan DER.

\section{DAFTAR PUSTAKA}

Adam, T., \& Goyal, V. K. (2008). The investment opportunity set and its proxy variables. Journal of Financial Research, 31(1), 41-63. https://doi.org/10.1111/j.1475-6803.2008.00231.x

Arikunto, S. (2006). Prosedur Penelitian : Suatu Pendekatan Praktik. Jakarta: PT Rineka CIpta.

Asmara, C. G. (2018). Kondisi Perekonomian Indonesia 2018 Menurut Sri Mulyani. cnbc.com (https://www.cnbcindonesia.com/news/20180108191250-4-929/kondisi-perekonomianindonesia-2018-menurut-sri-mulyani, diakses pada 5 Januari 2020)

Brigham, E. F., \& Houston. (2010). Fundamental of Financial Management: Dasar-Dasar Manajemen Keuangan (Edisi 10). Jakarta: Salemba Empat.

Detthamrong, U., Chancharat, N., \& Vithessonthi, C. (2017). Corporate governance, capital structure and firm performance: Evidence from Thailand. Research in International Business and Finance, 42(June), 689-709. https://doi.org/10.1016/j.ribaf.2017.07.011

Dogan, M. (2013). Does Firm Size Affect The Firm Profitability? Evidence from Turkey. Research Journal of Finance and Accounting, 4(4), 53-60.

Fachrudin, K. A. (2011). Analisis Pengaruh Struktur Modal, Ukuran Perusahaan, dan Agency Cost Terhadap Kinerja Perusahaan. Jurnal Akuntansi Dan Keuangan, 13(1), 37-46. https://doi.org/10.9744/jak.13.1.37-46

Ghozali, I. (2016). Aplikasi Analisis Multivarate dengan Program IBM SPSS 23 (8th ed.). Semarang: Badan Penerbit Universitas Diponegoro.

Gideon, A. (2018). Pasar Property di 2019 Lebih Positif. liputan6.com.(https://www.liputan6.com/bisnis/read/3802398/riset-rumahcom-pasar-propertidi-2019-lebih-positif), diakses pada 6 Januari 2020)

Horne, J. C. Van, \& Wachowicz, J. M. (2012). Prinsip-Prinsip Manajemen Keuangan (Edisi 13). Jakarta: Salemba Empat. 
Tri Indah Sri Mulyaningsih. Analisis Faktor pada Kinerja Keuangan dan Mediasi Struktur Modal pada Komite Audit di Perusahaan Property

Hutchinson, M., \& Gul, F. A. (2004). Investment opportunity set, corporate governance practices and firm performance. Journal of Corporate Finance, 10(4), 595-614. https://doi.org/10.1016/S0929-1199(03)00022-1

Hutchinson, M. R. (2005). An Analysis of the Association Between Firms' Investment Opportunities, Board Composition, and Firm Performance. SSRN Electronic Journal, (03). https://doi.org/10.2139/ssrn.295483

Idx.co.id. (2020). Laporan Keuangan dan Tahunan. (https://www.idx.co.id/perusahaantercatat/laporan-keuangan-dan-tahunan), diakses pada 2 Januari 2020)

Jensen, M. J., \& Meckling, Wi. H. (1976). Theory Of The Firm : Managerial Behaviour, Agency Cost and Ownership Structure. Journal of Financial Economics 5, 305-360(10), 1671-1696. https://doi.org/10.1177/0018726718812602

Kautsar, A. (2019). Profitability is a Mediation Variable of Debt on Dividend Payout Indonesian Agriculture Companies.Scholars Journal of Economics, Business and Management 6(2):143146. 10.21276/sjebm.2019.6.2.9

Kautsar, A. (2014). Analisis Pengaruh Firm Size, Der, Dan Sales Growth Terhadap Dividend Payout Ratio Dengan Roe Sebagai Variabel Intervening Pada Perusahaan Non Keuangan Yang Listed Di Bei Tahun 2009-2011. Jurnal Bisnis Strategi 23(2), 1-13. https://doi.org/10.14710/jbs.23.2.1-13

Kautsar, A., \& Kusumaningrum, T. M. (2015). Analisis Pengaruh Good Coorporate Governance Terhadap Kinerja Perusahaan Yang Dimediasi Struktur Modal Pada Perusahaan Pertambangan Yang Listed Di BEI 2009-2012. Jurnal Riset Ekonomi Dan Manajemen, 15(1), 59-75. http://dx.doi.org/10.17970/jrem.15.150105.ID

K, M., \& Akash, S. B. (2018). Corporate Governance and Financial Performance: An Empirical Study of Indian Companies. Journal of Management (JOM), 5(6), 213.

Kanwal, M., \& Hameed, S. (2017). The Relationship between Dividend Payout And Firm Financial Performance. Research in Business and Management, 4(1), 5. https://doi.org/10.5296/rbm.v4i1.10784

Kasmir. (2016). Analisis Laporan Keuangan. Jakarta: Rajawali Pers.

Kemenkeu.co.id. 2019. Pertumbuhan Ekonomi Indonesia Tahun 2018 Lebih Tinggi Dari Tahun 2017. (https://www.kemenkeu.go.id/publikasi/berita/pertumbuhan-ekonomi-indonesia-tahun-2018lebih-tinggi-dari-tahun-2017/), diakses pada tanggal 5 Januari 2020)

M'rabet, R., \& Boujjat, W. (2016). The Relationship Between Dividend Payments And Firm Performance: A Study Of Listed Companies In Morocco. European Scientific Journal, ESJ, 12(4), 469. https://doi.org/10.19044/esj.2016.v12n4p469

M, R., Waren, J. S., \& Carl. (2010). Pengantar Akuntansi Adaptasi-Indonesia. Jakarta: Salemba Empat.

Malhotra, N. K. (2009). Riset Pemasaran Pendekatan Terapan Jilid 1 (4th ed.). Jakarta: Indeks.

Marinda, F., AR, M. D., \& Saifi, M. (2014). Pengaruh Investment Opportunity Set (Ios) Dan Struktur Modal Terhadap Kinerja Keuangan (Studi Pada Perusahaan Sektor Property Dan Real Estate Yang Terdaftar Di Bursa Efek Indonesia Periode 2011-2013). Jurnal Administrasi Bisnis S1 Universitas Brawijaya, 14(1), 1-10. 
Modigliani, F., \& Miller, M. H. M. (1963). American Economic Association Corporate Income Taxes and the Cost of Capital: A Correction. American Economic Review, 53(3), 433-443. https://doi.org/10.1126/science.151.3712.867-a

Myers, S. C. (1977). Determinants of Corporate Borrowing. Journal of Financial Economics 5, $147-$ 175(10), 2063-2072. https://doi.org/10.1253/circj.CJ-16-0846

Nuzil, N. R. (2017). Journal Knowledge Industrial Engineering ( JKIE ) Keywords : Dividend policy, the company' s performance, and the value of the company. Journal Knowledge Industrial Engineering, 04(02), 41-50.

Olawale, L., Bamidele, I., \& Lawal, F. (2017). The effect of firm size on performance of firms in Nigeria El efecto tamaño en el rendimiento de las empresas nigerianas. The Ieb International Journal of Finance, 15(4), 2-21. https://doi.org/10.5605/IEB.15.4

Olayinka, O. M. (2019). Audit Committee and Firms Performance in Nigeria: Case Study of selected Nigerian Banks. International Journal of Scientific and Research Publications (IJSRP), 9(9), p9315. https://doi.org/10.29322/ijsrp.9.09.2019.p9315

Pervan, M., \& Visic, J. (2012). Influence of Firm Size on Its Business Success. Croatian Operational Research Review, 3(1), 213-223.

Pradhan, R. S., \& Paudel, L. (2017). Impact of Fundamental Factors on Stock Price: A Case of Nepalese Commercial Banks. SSRN Electronic Journal, (April). https://doi.org/10.2139/ssrn.3044108

Purwohandoko, Nadia Asandimitra, Yuyun Isbanah, dan Achmad Kautsar. 2014. Dasar-Dasar Manajemen Keuangan. Surabaya : Unesa University Press.

Putra, A., \& Badjra, I. (2015a). Pengaruh Leverage, Pertumbuhan Penjualan dan Ukuran Perusahaan Terhadap Profitabilitas. E-Jurnal Manajemen Universitas Udayana, 4(7), 2052-2067.

Putra, A., \& Badjra, I. (2015b). Pengaruh Leverage, Pertumbuhan Penjualan dan Ukuran Perusahaan Terhadap Profitabilitas. E-Jurnal Manajemen Universitas Udayana, 4(7), 249411.

S, N. (2016). The Impact of Capital Structure on Financial Performance of the Firms: Evidence From Borsa Istanbul. Journal of Business \& Financial Affairs, 5(2), 5-8. https://doi.org/10.4172/2167-0234.1000173

Sanjabi, M., \& Jamshidinavid, B. (2017). The Relationship between Corporate Performance, Investment Decisions, and Investment Opportunities: Evidence from Tehran Stock Exchange. Journal of Economic \& Management Perspectives, 11(4), 481-485. Retrieved from http://www.econ-society.org

Sanjaya, S., \& Rizky, M. F. (2018). Analisis Profitabilitas Dalam Menilai Kinerja Keuangan Pada PT. Taspen (Persero) Medan. Kitabah, 2(2), 1689-1699. https://doi.org/10.1017/CBO9781107415324.004

Sekaran, U. (2011). Metode Penelitian Untuk Bisnis. Jakarta: Salemba Empat.

Simatupang, P. I. A. N. (2019). Pengaruh Good Corporate Governance Terhadap Kinerja Keuangan Perusahaan Yang Di Mediasi Oleh Struktur Modal Dan Kebijakan Dividen Pada Perusahaan Manufaktur Yang Terdaftar Di BEI Pada Periode 2014-2016. Al-Iqtishad - Jurnal Ilmu Ekonomi Syariah, HG1-9999 F. 
Tri Indah Sri Mulyaningsih. Analisis Faktor pada Kinerja Keuangan dan Mediasi Struktur Modal pada Komite Audit di Perusahaan Property

Sudana, I. M. (2015). Manajemen Keuangan Perusahaan (Edisi Kedu). Jakarta: Erlangga.

Sugiyono. (2016). Metode Penelitian Pendidikan Pendekatan Kuantitatif, Kualitatif, dan $R \& D$. Bandung: Alfabeta.

Tarus, D. K., \& Ayabei, E. (2016). Board composition and capital structure: evidence from Kenya. Management Research Review, 39(9), 1056-1079. https://doi.org/10.1108/MRR-01-2015-0019

Tornyeva, K. (2012). Corporate Governance and Firm Performance: Evidence from the Insurance Sector of Ghana. 4(13), 95-113.

Tornyeva, K., \& Wereko, T. (2012). Corporate Governance and Firm Performance: Evidence from the Insurance Sector of Ghana. European Journal of Business and Management, 4(13), 95-113.

Tunggal, W. S. P., \& Fachrurrozie. (2014). Accounting Analysis Journal. Accounting Analysis Journal, 3(4), 457-465.

Waworuntu, S. R., Tjahjana, K. A. N. F., \& Rusmanto, T. (2017). The Effect of Corporate Governance on Firms' Capital Structure of Listed Companies in Sri Lanka. Journal of Competitiveness, 9(2), 19-33. https://doi.org/10.7441/joc.2017.02.02

Yuliani, Fuadah, L., \& Thamrin, K. H. (2018). Pengaruh Mediasi Bauran Pendanaan Terhadap Hubungan Set Peluang Investasi dan Profitabilitas Abstrak. Jurnal Bisnis Dan Manajemen, $2(1), 56-67$. 